DOI: http://dx.doi.org/10.26858/est.v1i1.6521

\title{
The Implementation of Flipped Classroom Learning Model Using Moodle To Increase Students' Higher Order Thinking Skills
}

\author{
Huzaima Mas'ud ${ }^{1}$, Herman Dwi Surjono ${ }^{2}$ \\ ${ }^{1}$ Informatic and Electronics Education, Universitas Negeri Yogyakarta, Indonesia \\ Email:huzaima.masud2016@ student.uny.ac.id \\ ${ }^{2}$ Informatic and Electronics Education, Universitas Negeri Yogyakarta, Indonesia \\ Email: hermansurjono@uny.ac.id
}

(Received: October-2018; Reviewed: October-2018;; Accepted: December-2018; Published: December-2018) access under license CC BY-NC-4.0 (https://creativecommons.org/licenses/by-nc/4.0/ ).

\begin{abstract}
This study aims to reveal the differences in the learning achievement based on higher order thinking skills of the students using flipped classroom learning model with moodle media on simulation and digital communication subjects and that of those using the conventional learning model with printed book media. This research was a quasi experiment in the form of pre-test and post-test group. The population was all students of class X TKJ SMK Negeri 3 Kab.Pinrang, totaling 62 students. The sample was established using intact group technique based on the existing class. The data were collected through a test to measure student learning achievement based on higher order thinking skills, a questionnaire with Likert scale, and documentation. Measurements were based on students' learning achievement scores and responses to the flipped classroom learning model. The data were analyzed using the descriptive statistics and inferential statistics. The results shows that, there were differences in students' learning outcomes based on higher order thinking skills using flipped classroom learning model with moodle media on simulation and digital communication subjects compared with learning outcome using conventional learning model / lecture with printed book media, namely the mean of experimental class groups 30.41 while the control class group 27.70 from the highest score 35 in the experimental class and 33 in the control class and proved by results of hypothesis testing with a probability value of $0.032<0.05 \mathrm{H}_{1}$ accepted.
\end{abstract}

Keywords: flipped classroom; moodle; higher order thinking skill

\section{INTRODUCTION}

The 21st century is the digital age. A teacher must design learning that will lead the students to meet the needs of the 21 st century. Griffin et.al (2012) The ability of the 21 st century should be possessed by learners, namely: (1) Ways of thinking, which is the ability to think that must be mastered by the students to face the world of the 21 st century. Thinking abilities are: creative, critical thinking, problem solving, decision making and learning; (2) Ways of working, the ability of how they should work with a global world and the digital world; (3) Tools for working. One must have and master the tools to work. Mastery of Information and communications technology (ICT) and infor-mation literacy is a must; (4) Living in the world. ability to live life in the 21 st century, namely: Citizenship, life and career, and personal and social responsibility. 
Pisa (2015) The level of ability of Indonesian students is very low in: (1) understanding of complex information; (2) theory, analysis and problem solving; (3) the use of tools, procedures and problem solving; and (4) conducting an investigation. These four powers are known for high-order thinking or Higher Order Thinking Skills (HOTS). Lewis and Smith (1993) Some categories of higherorder thinking are: (1) problem solving; (2) critical thinking; (3) creative thinking and (4) decision making.

Lutz-Christian and Jenny (2016) The Flipped Classroom model is not only an effective way of learning. In contrast, this new model can also teach students information technology (IT) literacy which is crucial for success in the modern legal profession, combining the use of learning model and information and communication technology (ICT) using moodle instruction will help improve student learning outcomes at a high level of thinking ability.

Higher Order Thinking Skills HOTS includes (1) Critical Thinking, (2) Problem Solving, (3) Decision Making, and (4) Creative Thinking Lewis and Smith (1993). The fourth thing is a way of thinking that is used to facilitate someone in achieving the goal or solve a problem. In the process of learning, a teacher will not be separated from the right strategy used in achieving optimal learning outcomes. Higher Order thinking skill (HOTS) thinking ability is the result of a learning process, one of the causes of the low way of student thinking because the teacher is still using conventional approach which indirectly does not stimulate the increase of thinking of Higher Order Thinking Skills (HOTS). Transferring the possessed knowledge and then applying it to real life means already identifying high-level thinking. Critical thinking about something as logical and contemplative thinking that is centered on something that is actually to be believed or done, it includes skills that enable students to distinguish between non-credible and credible sources, illustrate assumptions, categorizations and biases; to understand the content and motives of the text, be able to analyze, assess and evaluate.

Problem solving included in the Higher Order Thinking Skills category includes remembering information, understanding learning and then critically assessing, making innovative choices and articulating it, this is a clear picture of whether or not a person facing or solving the problem has high-order thinking. Widana (2017) Higher-Order Thinking Skills usually require students to solve problems, organize and identify patterns, define relationships and create new ideas from known information, and recognize there are multiple points of view in answering a given problem in accordance with the learning objectives to be achieved, Fianti, et.al. (2016) by using the openended model.

Brookhart (2010) Assessment methods used to assess the students' ability of HOTS can use 3 methods, namely (1) presenting something for students to think about, usually in the form of introductory text, visuals, scenarios, source material, or similar problems; (2) use new learning content for students, not included in the classroom so students can remember; (3) distinguish between difficulty level (easy vs difficult) and thinking level (low order thinking vs high thinking), and control for each of these separate orders of thought.

Flipped classroom was first introduced in 2007 in the United States by Jonathan Bergman and Aroon Sams. In essence, the concept of a flipped classroom learning model is when the usual learning done in the classroom is done by the students at home, and the usual homework done at home, completed in school, Bregmann and A.Sams (2012). Flipped classrooms are a way that teachers can provide by minimizing the number of direct instructions in their teaching practice while maximizing interaction with each other, Graham (2013). Utilization of technology in education makes some new learning models emerging, among them is Flipped Classroom. It utilizes technology that provides additional supportive learning materials for students accessible online.

This frees up the class time that has previously been used for learning. Flipped classroom model is not just learning to use learning video, but it emphasizes more on utilizing time in class for better quality learning and it can increase student's knowledge. Lesson material has been learned at home through video media so that students have more time in the class to do tasks, exercise questions, projects, or discussions related to material that has been submitted by the teacher through video at a previous time. Learning using the flipped classroom model has relevance to Bloom's taxonomy. Bloom's Taxonomy in the cognitive domain has six categories from the lowest to the 
highest of knowledge, understanding, application, analysis, synthesis, and evaluation. Conventional learning categories of knowledge and understanding take place in the classroom while the categories of application, analysis, evaluation, and creation are achieved through homework, Brame (2013).

Moodle is a name for an application program that can transform a learning medium into a web form. Moodle is provided free of charge as Open source software under the license of GNU Public License which means that despite copyright, moodle still gives users the freedom to copy, use and modify it. Cole and Foster, (2008) Moodle as an abbreviation of the Modular Object-Oriented Dynamic Learning Environment which means a dynamic learning place using an object-oriented model, with educators getting their skills in online teaching derived from the experience of doing online activities, which is obtained from learning by doing, Wahyuningsih and Makmur (2017).

Through Moodle, teachers have also used various technology-focused teaching techniques to help their students engage in numerous learning contents, such as language, literature, or social sciences by planning a greatly evolving concept of place and time, Jeong (2016). The advantages of Moodle are: (1) Simple, efficient and lightweight, and compatible with many browsers; (2) Easy installation with support in multiple languages, including Bahasa Indonesia; (3) The availability of site management for overall site setup, module changes, and so on; and (4) The availability of user management and good course management. Amiroh (2012) The easy installation to construct an e-learning is one of the considerations that researchers choose Moodle as the e-learning base to be developed.

Based on the theoretical study and frame of mind as described, the research hypothesis can be formulated as follows: Ho: $\mu_{1}$ $=\mu_{2}$ there is no difference in the results of higher order thinking skills based learning students using flipped classroom learning models with moodle media on simulation subjects and digital communication compared to learning outcomes using conventional learning models/lectures with printed book media).

$\mathrm{H}_{1}: \mu_{1} \neq \mu_{2}$ there are differences in the results of higher order thinking skills based learning students using flipped classroom learning models with moodle media on simulation subjects and digital communication compared to learning outcomes using conventional learning model /lectures with printed book media.

\section{METHOD}

The form of research used by the researcher is quasi Experimental design by using non equivalent control group design (pretest, posttest which is not equivalent), that is the distribution of research sample which is intended to know or try to examine the existence of causal relationship by comparing between experimental group that has been given treatment with comparison group that has no treatment, the treatment referred to in this study is the use of the flipped classroom learning method. This experimental method was chosen to test the influence of one or more variables on other variables or causal relationships of one or several variables.

Population in this research is all students of class $X$ TKJ SMKN 3 Pinrang, $X$ TKJ 1 with the number of 30 students and class $\mathrm{X}$ TKJ 2 with 32 students so total population in this research, is 62 students. The sample is the partial or representative of the population studied, the sample is not randomly assigned or not through the random assignment process but determined based on the existing class (Intact Group) which is class $\mathrm{X}$ TKJ 1 as the experimental class and class $\mathrm{X}$ TKJ 2 as the control class, the number of samples in this study as many as 62 students. Data collection in this research is done by some technique, that is: test and non test. The test technique is used to measure students' basic skills and higher order thinking skills based learning outcomes. The test is conducted twice at the beginning of the research activity (pre-test) and at the end of the research activity (post-test), while non-test technique is used to measure flipped classroom learning model used in teaching and learning process using questionnaire, questionnaire is given to get data about students' views about the model in improving higher order thinking skill.

This research uses reliability test with Alpha Crobanch formula. Reliability means trustworthiness or dependability (Arikunto, 2005: 171). Calculation of instrument reliability value is calculated using SPSS software. Instrument reliability test results show the value of 0.866 so that the questionnaire instrument pertained in a very high level of reliability. 
Table 1. Reliability

\begin{tabular}{cc}
\hline \multicolumn{2}{c}{ Reliability Statistics } \\
\hline Cronbach's Alpha & N of Items \\
.866 & 10 \\
\hline
\end{tabular}

\section{RESULT AND DISCUSSION}

The implementation of this research is conducted at State Vocational School 3 Pinrang, Pinrang District, all research activities, from the implementation of treatment to the data collection was conducted in the odd semester of the academic year 2017/2018, precisely in February 2018 until March 2018. Research includes data taking by spreading the closed questionnaire to the students. The number of questionnaires distributed was 62 questionnaires. For the next calculation (precondition test and hypothesis test) used a significance level of 5\% (0.05). The overall data obtained is considered reasonable to be analyzed. The data is then processed using SPSS software.

Table 2. Descriptive Statistics

\begin{tabular}{cccccc}
\hline \multirow{2}{*}{ NO. } & \multirow{2}{*}{ STATISTIC } & \multicolumn{2}{c}{ PRE-TEST } & \multicolumn{2}{c}{ POST-TEST } \\
\cline { 3 - 6 } & & Control & Experimental & Control & Experimental \\
\hline 1 & N & 17 & 17 & 17 & 17 \\
2 & Mean & 20.05 & 24.70 & 27.70 & 30.41 \\
3 & Std.Deviation & 5.11 & 3.21 & 3.21 & 3.65 \\
4 & Maximum score & 26 & 33 & 33 & 35 \\
5 & Minimum score & 9 & 18 & 21 & 25 \\
\hline
\end{tabular}

Based on table 2, the number of research subjects in both the control class and experimental class were 17 , the mean post-test results in control class increases compared to the pre-test results performed before, the same goes to experimental class which also increases after each class has been given treatment. The score difference is seen in maximum and minimum score in each class, experimental class has the highest score after being given treatment, while the lowest score is in control class. This proves that the applied treatment can positively affect the score improvement achieved by each student.

Description of Pre-Test and Post-Test data of Control Class

Table 3. Pre-test Distribution Data of Control Class

\begin{tabular}{cccc}
\hline Interval & Frequency & Percentage & Category \\
\hline $25-36$ & 3 & $17.65 \%$ & Very Good \\
$20-24$ & 6 & $35.29 \%$ & Good \\
$14-19$ & 5 & $29.41 \%$ & Fair \\
$9-13$ & 3 & $17.65 \%$ & Poor \\
Total & 17 & $100 \%$ & \\
\hline
\end{tabular}

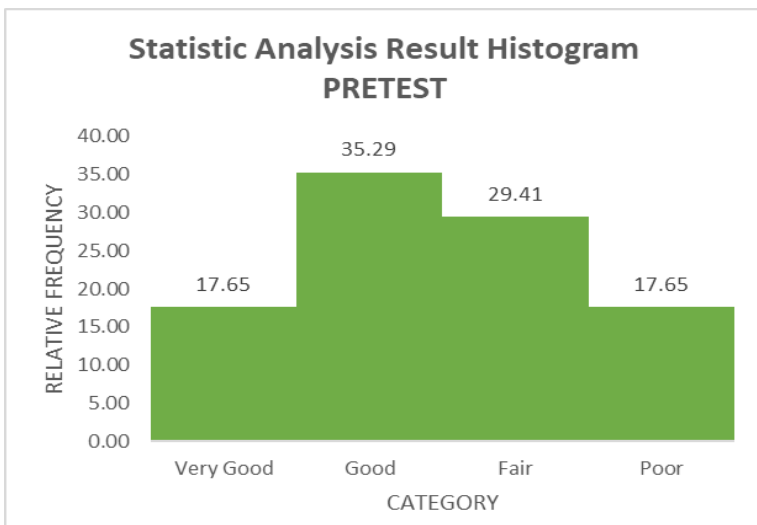

Figure. 1. Score Analysis Result Histogram of Post-test in Control class

Based on the table above, it shows that the pre-test learning result of control class, the dominant result of the student is in the very good category that has the percentage of $17.65 \%$ with 3 respondents, the good category has the percentage of $35.29 \%$ with 6 respondents, in fair category with the percentage of $29.41 \%$ with 5 respondents, poor category has a percentage of $17.65 \%$ with 3 respondents. Based on the data that have been processed, it can be concluded that the pre-test results in the control class are in good category. 
Table 4. Pre-test Distribution Data of Experimental Class

\begin{tabular}{cccc}
\hline Interval & Frequency & Percentage & Category \\
\hline $25-36$ & 14 & $82.35 \%$ & Very Good \\
$20-24$ & 3 & $17.65 \%$ & Good \\
$14-19$ & 0 & $0 \%$ & Fair \\
$9-13$ & 0 & $0 \%$ & Poor \\
Total & 17 & $100 \%$ & \\
\hline
\end{tabular}

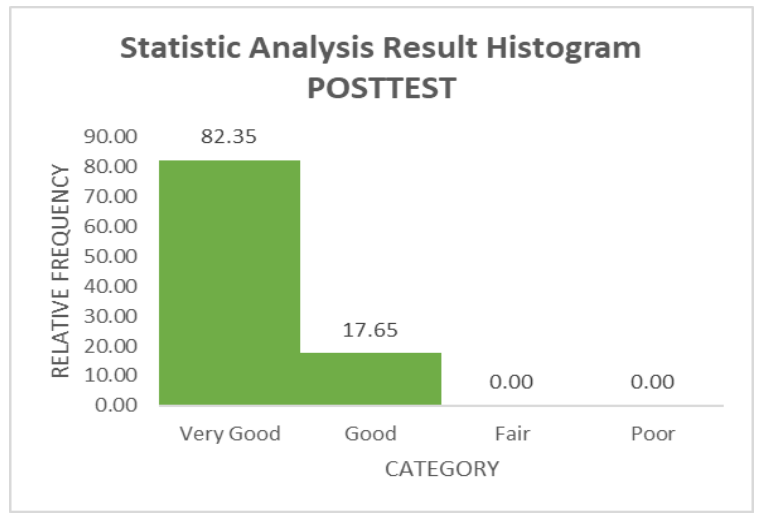

Figure.2. Score Analysis Result Histogram of Post-test in Control class

Description of Pre-Test and Post-Test data of Experimental Class. Based on table 4, it shows that the learning result of post test in control class, very good category has the percentage of $82.35 \%$ with 14 respondents, good category has the percentage of $17.65 \%$ with 3 respondents, fair and poor category each has $0 \%$ with none respondents. It can also been seen on picture 2. Score Analysis Result Histogram of Post-test in Control class. Based on the processed data, it can be concluded that the posttest result in control class is in very good category.

Table 5. Pre-test Distribution Data of Experimental Class

\begin{tabular}{cccc} 
Interval & Frequency & Percentage & Category \\
\hline $25-36$ & 7 & $41.18 \%$ & Very Good \\
$20-24$ & 8 & $47.06 \%$ & Good \\
$14-19$ & 2 & $11.76 \%$ & Fair \\
$9-13$ & 0 & $0 \%$ & Poor \\
Total & 17 & $100 \%$ & \\
\hline
\end{tabular}

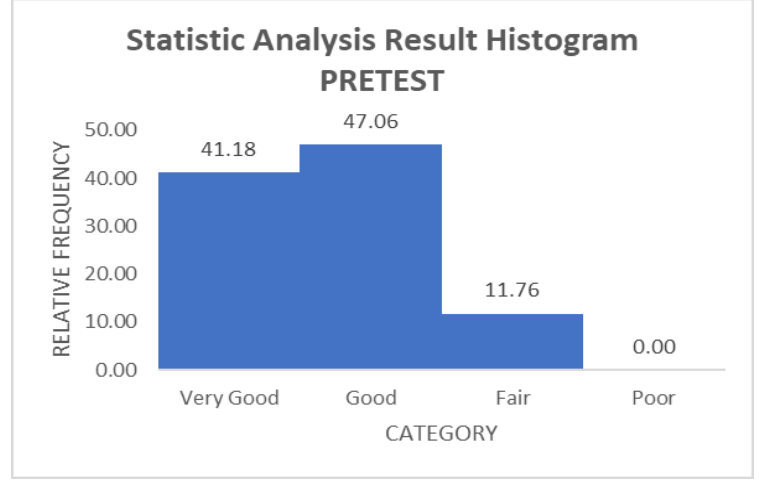

Figure 3. Score Analysis Result Histogram of Pre-test in Experimental class

Table 5 shows that in pre-test learning result of experimental class, the very good category has the percentage of $41.18 \%$ with 7 respondents, good category has the percentage of $47.06 \%$ with 8 respondents, fair category has the percentage of $11.76 \%$ with 2 respondents, none of the students is in the poor category. It can be seen in picture 3 Score Analysis Result Histogram of Pre-test in Experimental class. Based on the processed data, it can be seen that the pre-test result in experimental class is in good category.

Table 6. Post-test Distribution Data of Experimental Class

\begin{tabular}{cccc}
\hline Interval & Frequency & Percentage & Category \\
\hline $25-36$ & 17 & $100 \%$ & Very Good \\
$20-24$ & 0 & $0 \%$ & Good \\
$14-19$ & 0 & $0 \%$ & Fair \\
$9-13$ & 0 & $0 \%$ & Poor \\
Total & 17 & $100 \%$ & \\
\hline
\end{tabular}

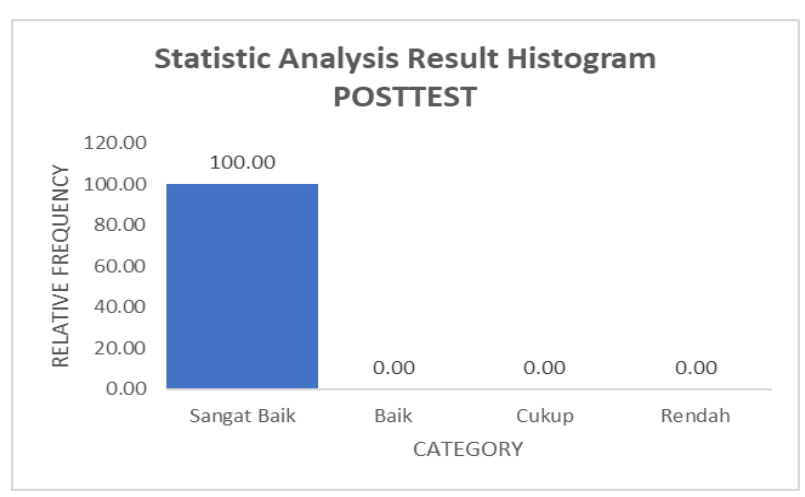

Figure 4. Score Analysis Result Histogram of Post-test in Experimental class

Table 6 shows that post-test learning result of experimental class, very good category has the percentage of $100 \%$ with 17 respondents in total, none of the students is in the good, fair, 
or poor category. It can also be seen in picture 5 . Score Analysis Result Histogram of Post-test in experimental class. Based on the processed data, it is concluded that post-test result in experimental class after receiving treatment is in very good category, it also shows that there is tendency of improvement of hots based learning outcome after the treatment is implemented.

Questionnaire Data Description of Flipped Classroom model. The results of descriptive analysis of the questionnaire show an overview of the students' of class X TKJ 1 perception on the implementation of flipped classroom learning methods in simulation and digital communication subject. Results of the questionnaire descriptive analysis showed the mean value obtained is 32.125 from the total sample of 24 people. The percentage form of descriptive analysis results of the questionnaire in this study can be seen in table 7 .

Table 7. Questionnaire Frequency Distribution

\begin{tabular}{ccccccc}
\hline CATEGORY & \multicolumn{3}{c}{ Class Interval } & $\begin{array}{c}\text { Absolute } \\
\text { Frequency }\end{array}$ & $\begin{array}{c}\text { Relative } \\
\text { Frequency } \\
(\boldsymbol{\%})\end{array}$ & $\begin{array}{c}\text { Cumulative } \\
\text { Frequency } \\
(\boldsymbol{\%})\end{array}$ \\
\hline Strongly Agree & 35 & To & 40 & 7 & 29.17 & 29.17 \\
Agree & 30 & To & 34 & 8 & 33.33 & 62.50 \\
Disagree & 25 & To & 29 & 5 & 20.83 & 83.33 \\
Strongly Disagree & 20 & To & 24 & 4 & 16.67 & 100.00 \\
Total & & & 24 & 100 & \\
\cline { 1 - 2 }
\end{tabular}

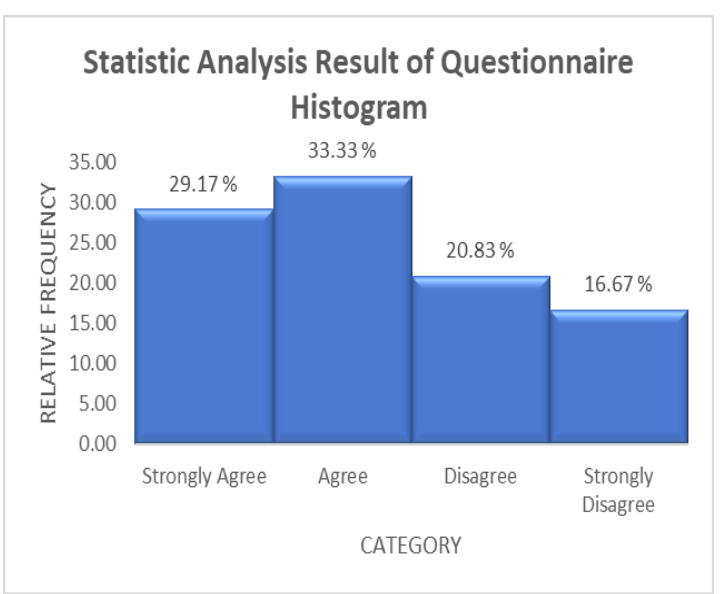

Figure. 5. Statistic Analysis Result of Questionnaire Histogram

Table 7 shows the analysis result of questionnaire, the percentage of $29.17 \%$ with 7 respondents choose strongly agree, the percentage of $33.33 \%$ with 8 respondents choose agree, $20.83 \%$ with 5 respondents choose disagree, and $16.67 \%$ with 4 respondents choose strongly agree. It can be seen in picture 5 statistic analysis result of questionnaire histogram. Based on the data collected, it is concluded that the result of questionnaire about students' perception on the implementation of flipped classroom learning methods in simulation and digital communication subject is in Agree category.

\section{Discussion}

The first hypothesis test in this research is: hypothesis (H1) there is a difference between students' learning outcome based on higher order thinking skills using flipped classroom learning model with moodle media in simulation and digital communication subject compared with students' learning outcome using conventional learning model / lecture with printed book media, while hypothesis (H0) there is no difference in students' learning outcome based on higher order thinking skills using flipped classroom learning model with moodle media in simulation and digital communication subject compared with students' learning outcome using conventional learning model / lecture with printed book media. The statistic equation used is the t-test of two-sided test. The decision making of the hypothesis test is $\mathrm{H} 1$ accepted if thitung $\geq$ ttabel with significant level 0.05 .

Test results using t-test on both sides show that the value of $t$ count $=2.29$ is greater than ttable $=1.74$, then $\mathrm{H} 0$ is rejected and $\mathrm{H} 1$ is accepted. This proves that (H0) there is no difference in students' learning outcome based on higher order thinking skills using flipped classroom learning model with moodle media in simulation and digital communication subject compared with students' learning outcome using conventional learning model / lecture with printed book media is rejected, whereas (H1) there is a difference between students' learning 
outcome based on higher order thinking skills using flipped classroom learning model with moodle media in simulation and digital communication subject compared with students' learning outcome using conventional learning model / lecture with printed book media is accepted.

These results indicate that the use of certain learning models such as flipped classroom by utilizing moodle as a medium in teaching and learning process proved to be able to increase students' understanding in answering the problem of higher order thinking skills based that is given. Students in the experimental class may not be aware that the applied learning model directly changes the way they learn who previously had only heard the teacher's explanation of the material taught in the classroom as the center of learning is now quite the contrary, the students who become the center in learning with more interaction because before entering the class, students get the material through the moodle media or commonly referred to as pre-reading and students are required to study the material and ask things that are not understood as a discussion material at the time of learning in the classroom. This style of learning can improve the way students think, from low order thinking skills then switch to higher order thinking skill. This is the purpose and core of the learning model of flipped classroom.

\section{CONCLUSION AND SUGGESTION}

This study aims to analyze the difference of thinking improvement of students' Higher Order Thinking Skill after using the learning model of flipped classroom by utilizing Moodle as a learning medium, compared to using conventional learning model by utilizing printed book as learning media. Analyzing the influence of the use of flipped classroom learning model can increase Higher Order Thinking Skill students. Analyzing the use of moodle as a medium of learning can increase the students' Higher Order Thinking Skill.

Based on the results of research conducted, it is found that the learning model flipped classroom with moodle as a medium of learning used positively affect the students' higher order thinking skill learning based learning outcome. Students' learning outcomes in simulation and digital communication subjects using flipped classroom learning model with moodle media tends to improve compared to students' learning outcomes that still use conventional learning model / lecture by using printed book as teaching media. Therefore, the use of learning model will affect the results to be achieved in a teaching and learning process, and the use of online media such as moodle in the learning process will greatly help achieve students' higher order thinking skills based learning outcome.

Limitations of this study are this study does not compare with other learning models such as problem-based learning and so on in an effort to improve the thinking level of students and not all students in each class were sampled due to the lack of attendance of students at the time of following the process of teaching and learning in school.

Teachers, especially teachers who teach simulation and digital communication subjects, are expected to use the flipped classroom learning method in implementing the teaching and learning process as a method to assist in achieving learning objectives which is based on improving students' thinking at higher order thinking skill level. Utilization of moodle learning media in order to maximize its use as an alternative that students can use for prereading means, in the use of moodle as a medium of learning, it is expected there is a follow-up similar study. Researchers can involve teachers directly to create teaching materials in the form of video learning as the material of the students to do pre-reading before the learning process in the classroom is implemented. The results of this study is expected to be used as a consideration to create teaching and learning strategies in an effort to increase the level of thinking of students to high level or higher order thinking skill.

\section{REFERENCES}

Griffin, P., McGaw, B., \& Care, E., (Eds.) (2012). Assessment and teaching of 21st century skills. Dordrecht: Springer.

Programme For Internasional Student Assessment (PISA). (2015). Result in Focus. OECD.

Lewis, A. and Smith, D. (1993). Defining Higher Order Thinking. Tylor \&Francis, Ltd. 
Lutz-Christian Wolff and Jenny Chan. (2016). Flipped Classrooms for Legal Education, published by Springer Nature.

J.Bregmann and A.Sams, (2012). Flip Your Classroom: Reach Every Student in Every Class Every Day, Washington DC: International Society for Technology in Education.

Graham Brent. Johnson, (2013). Student Perceptions of The Flipped Classroom, Columbia: The University Of British Columbia.

Brame,C.J, (2013). Flipping the Classroom, Nashville: Vanderbilt University.

J. Cole, H. Foster, (2008). Using Moodle: Teaching with the Popular Open Source Course Management System O'Reailly Media Inc, Sebastopol.

Wahyuningsih D, Makmur R. (2017), Elearning: teori dan aplikasi, informatika bandung. Bandung.
Jeong, K. O., (2016). "Integrating a web-based platform to promote creativity and authenticity in language classrooms", International Journal Knowledge and Learning, Vol. 11, Nos, 2/3, 2016, pp. 127136.

Amiroh. (2012), Membangun E-Learning dengan Learning Management System, Genta. Group Production: Sidoarjo

Widana, I.W. (2017). Modul Penyusunan Soal Higher Order Thonking Skill (HOTS). Jakarta: Dirjen PSMA

Fianti, F.L. Najwa and S. Linuwih (2016). Development of Open-Ended Problem for Measuring The Higher Order Thinking Skills of High School Students on Global Warming Phenomenon. Journal of Physics: Conf.Series 824.

Brookhart, S.M., (2010). Assess Higher-Order Thinking Skills in Your Classroom. Virginia: ASCD

Arikunto, Suharsimi. (2005). Manajemen Penelitian. Jakarta: RinekaCipta 